DP-1197

Metals, Ceramics, and Materials

(TID-4500)

\title{
SILICATES AS INHIBITORS OF ALUMINUM CORROSION IN SAVANNAH RIVER REACTORS
}

\author{
by \\ Robert s. Ondrejcin
}

Approved by

R. T. Huntoon, Research Manager

Nuclear Materials D1vision

December 1969

E. I. DU PONT DE NEMOURS \& COMPANY

SAVANNAH RIVER LABORATORY

AIKEN, S. C. 29001

CONTRACT AT(07.2).1 WITH THE

UNITED STATES ATOMIC ENERGY COMMISSION 


\section{ABSTRACT}

The corrosion rate of aluminum cladding on fuel elements in Savannah River reactors was reduced by lithium silicate. Fuel tubes were treated to form a film of lithium aluminosilicate about 1 micrometer thick on the aluminum surfaces. Corrosion of treated aluminum surfaces decreased as much as $50 \%$ after four days. After 50 to 60 days of reactor operation, treated and untreated aluminum had the same oxide thickness. Corrosion of both treated and untreated aluminum decreased $30 \%$ (on the basis of hydrogen evolution) due to the addition of a maximum of $0.5 \mathrm{ppm}$ combined soluble and polymeric silica. to the moderator. The addition also decreased the turbidity by reducing the concentration of hydrated aluminum oxides to $<0.5 \mathrm{ppm}$, and consequently decreased the concentration of the associated fission products. 


\section{CONTENTS}

Page

List of Tables and Figures .............. 4

Introduction ................... 5

Summary ..................... 6

Discussion ................. 7

Inhibitor Selection ............ . 7

Experimental Procedures . . . . . . . . . . . . 9

Filming and Testing Laboratory Specimens... . . 9

Filming and Testing Reactor Components..... . 9

Analyses of stlicates . . . . . . . . . 9

Results .................. . . 10

Laboratory Evaluation of Silicate Inhibitor . . 10

Reactor Tests - Addition of Silicates to

Moderator .............. 12

Untreated cladding . . . . . . . . . 12

Treated cladding . . . . . . . . . 15

Acknowledgments . . . . . . . . . . . . 19

References ................. . . 19 


\section{LIST OF TABLES AND FIGURES}

Table

Page

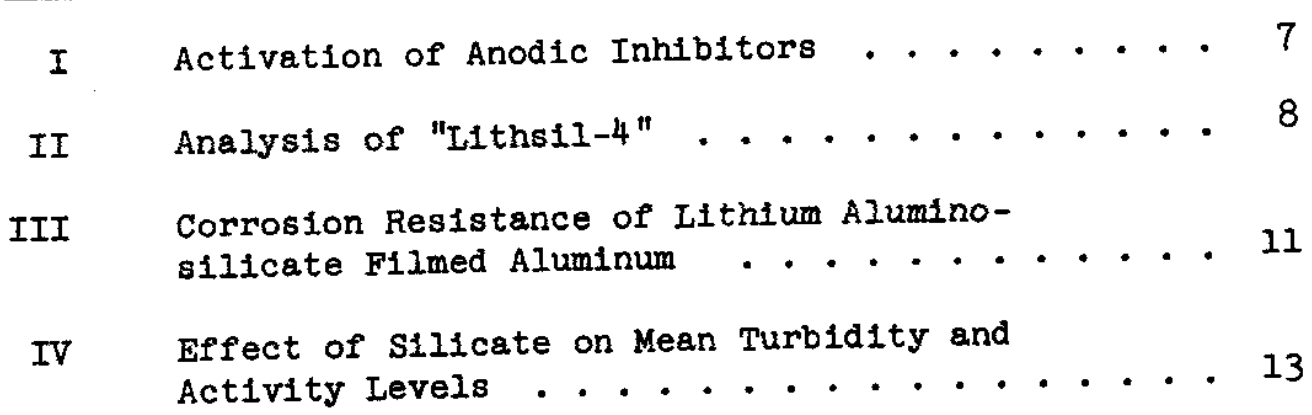

Figure

1 Savannah River Reactor Coolent System ..... 5

Aluminum Components Filmed with Lithium
Aluminosilicate ................ 10

3 Laboratory Corrosion Tests of Aluminum . . . . 11

4 Effect of Silicate Addition on Moderator Activities .............. 13

6 Profile of Corrosion Product on Fuel Cladding after S1X Months Exposure ......... 16

7 Calculated Long-Term Corros:cn . . . . . 17

8 Calculated Short-Term Corrosion . . . . . 18 


\section{INTRODUCTION}

The reactors at the Savannah River Plant (SRP) are cooled and moderated with heavy water. The two primary metals in the reator system are austentic stainjess steel and aluminum. The heavy water is purified by ion exchange and recirculated through the stainless steel reactor tank, heat exchangers, pumps, and associated piping (Figure 1).

The fuel cladding and housing tubes charged into the reactor tank are fabricated from aluminum. To permit longer fuel cycles and higher fuel temperatures, corrosion of the aluminum cladding must be minimized. Corrosion has been controlled adequately by adjusting the deuterium ion concentration to $a \mathrm{pD}$ of $5.1 .^{2}$

This report describes laboratory and in-reactor corrosion tests that demonstrate additional protection of aluminum by lithium silicate. In commercial practice, about $10 \mathrm{ppm}$ of soluble silica inhibits corrosion of aluminum in aqueous systems. ${ }^{2}$

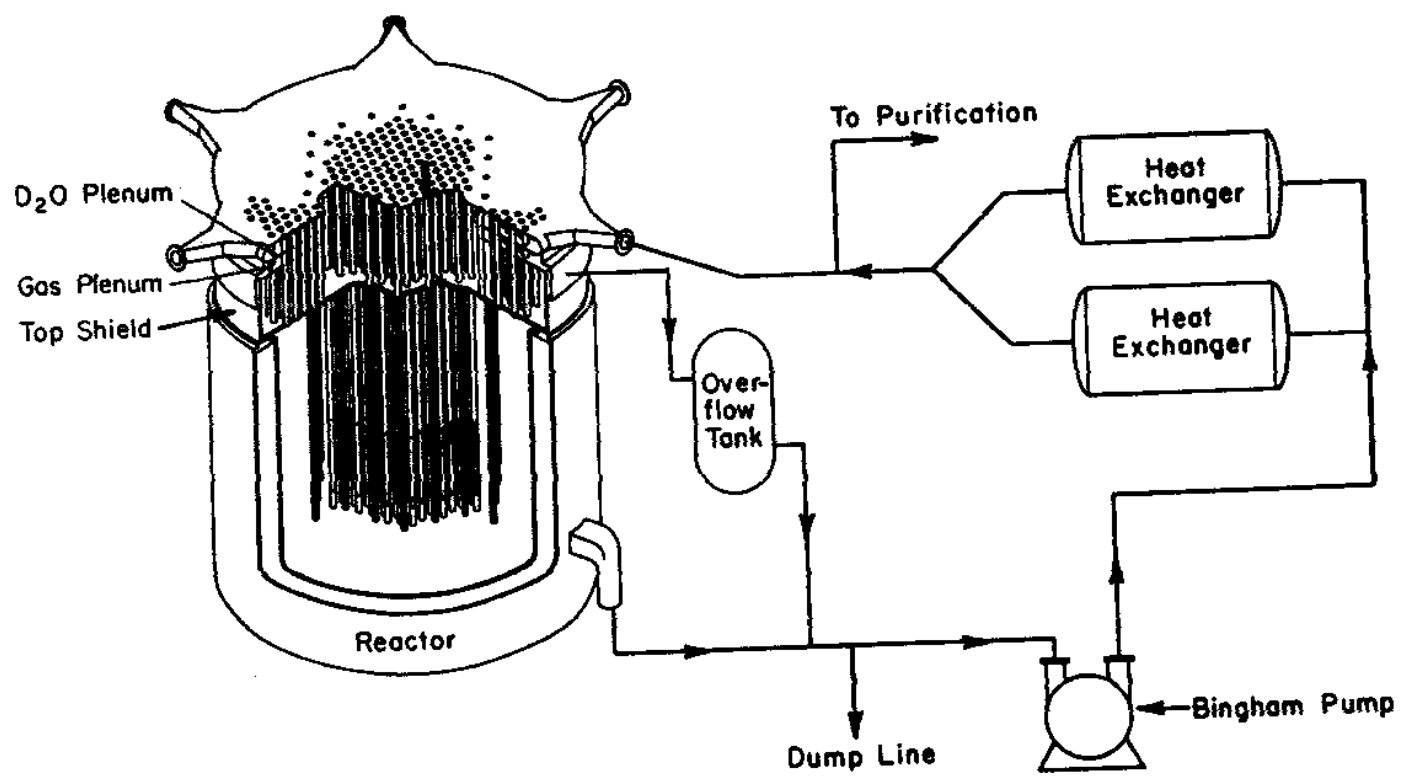

FIG. I SAVANNAH RIVER REACTOR COOLANT SYSTEM (SIMPLIFIED) 


\section{SUMMARY}

Lithium sillcate was selected as an aluminum corrosion inhibitor in the recirculating heavy water reactor systems at Savannah River because it is: 1) stable in an oxidizing aqueous solution under neutron bombardment, and 2) effective at low concentrations (to minimize depletion of the ion exchange purification system).

Laboratory evaluation in a static test system showed that corrosion in water at $\mathrm{pH} 5$ was reduced by a factor of two after treatment of a clean aluminum surface with colloldal silica followed by immersion in a heated solution of lithium silicate.

Tests in an operating reactor confirmed that ilthium aluminosilicate films grown on clean aluminum surfaces prior to reactor charging do inhibit corrosion. A film $\sim 1$ um thick reduced the corrosion rate by about $50 \%$ early in the reactor cycle, producing a maximum difference between filmed and untreated components after 4 days. However, after 50-60 days, fllmed and untreated aluminum had the same thickness of oxide. A maximum of $0.5 \mathrm{ppm}$ soluble sillca added to the moderator as lithium silicate $\left(\mathrm{SiO}_{2} / \mathrm{LI}_{2} \mathrm{O}=4 / 1\right)$ was not sufficlent to maintain protection of the I- $\mu \mathrm{m}$-thick Pilm.

In these tests, the addition of silica as lithium silicate was found to reduce the corrosion, as measured by the generation of corrosion-product hydrogen. Reduction was $~ 30 \%$ during $81 x$-month tests of both treated and untreated loads. Furthermore, at a maximum of $0.2 \mathrm{ppm}$ soluble silica, lithium silicate was also highly effective in reducing moderator turbidity by coagulating hydrated aluminas, which result from aluminum corrosion. ${ }^{55} \mathrm{Zr}-95 \mathrm{Nb}$ and ${ }^{203} \mathrm{Ru}$ 118sion product activity associated with the turbidity was also reduced. 


\section{DISCUSSION}

\section{INHIBITOR SELECTION}

In the reactor hydraulic system, heavy water is recirculated and purified by ion exchange. A corrosion inhibitor in this type of system has two major requirements. First, the inhibitor must be stable under neutron bombardment in an oxidizing system. Second, the inhibitor must cause minimum depletion of the ion exchange resin. Organic inhibitors are unstable in peroxide solutions under neutron bombardment; degradation products would produce large quantities of $\mathrm{CO}_{2}$ and could foul fuel surfaces. Cathodic inhibitors are only effective at high concentrations, but these concentrations would rapidly deplete the ion exchange resin.

Anodic inhibitors, those that generally retard the anodic reaction $\mathrm{Al} \rightarrow \mathrm{Al}^{+s}+3 \mathrm{e}^{-}$and therefore decrease the cathodic reaction $2 \mathrm{H}^{+}+2 \mathrm{e} \rightarrow \mathrm{H}_{2}$ an equivalent amount, are normally effective at fairly low concentrations. The stability of four inhibitors to transmutation and the concentrations typically used to control corrosion in water are shown in Table $I$. The data were calculated on the basis of a total flux of $2.6 \times 10^{20}$ neutrons $/ \mathrm{cm}^{2}$.

Table I. Activation of Anodic Inhibltors

\begin{tabular}{|c|c|c|c|}
\hline Inhibitor & $\begin{array}{c}\text { Effective } \\
\text { Conc, } \\
\text { ppm } \\
\end{array}$ & $\begin{array}{l}\text { Act1ration } \\
\text { Product } \\
\end{array}$ & $\begin{array}{c}\text { Product Activity, } \\
\text { curles } / \mathrm{g} \\
\text { of element }\end{array}$ \\
\hline $\mathrm{CrO}_{4}=$ & 200 & ${ }^{11} \mathrm{Cr}$ & 12 \\
\hline $\mathrm{PO}_{4} \equiv$ & 10 & ${ }^{32} \mathrm{P}$ & 7.5 \\
\hline $\mathrm{S} \mathrm{O}_{3}=$ & 10 & $32 \mathrm{p}$ & $5 \times 10^{-0}$ \\
\hline $\mathrm{TCO}^{-}$ & 5 & ${ }^{100} \mathrm{Ru}$ & 0 \\
\hline
\end{tabular}

Silicate was selected based on cost, effective concentration, and activation product generation. Pertechnetate is effective at the lowest concentration, but its high cost would require reprocessing the purification system ion exchange resin to recover the inhibitor. Although its activation product is nonradioactive, technetium itself is radioactive. Chromate and phosphate would require special spent fuel cooling facilities to prevent the ${ }^{31} \mathrm{Cr}$ and ${ }^{32} \mathrm{p}$ from reaching the $100 \mathrm{cl}$ environment. 
Silicates can be used as lithium, sodium, or potassium salts. The cation that would produce the least troublesome activation product is lithium. The predominant thermal neutron reaction

$$
{ }^{8} \mathrm{Li}_{3}+{ }^{1} \mathrm{n}_{\mathrm{O}} \rightarrow{ }^{3} \mathrm{H}_{\mathrm{I}}+{ }^{4} \mathrm{He}_{2}
$$

would produce tritium and helium. Tritium is already present in the moderator because of the absorbtion of neutrons by the deuterium oxide moderator. Sodium would produce ${ }^{24} \mathrm{Na}$, a $2.75-\mathrm{MeV}$ gamma emitter, and potassium would produce ${ }^{42} \mathrm{~K}$, a $1.52-\mathrm{Mev}$ gamma emitter.

Both lithium meta- and orthosilicates $\left(\mathrm{LI}_{2} \mathrm{SiO}_{3}\right.$ and $\left.\mathrm{Li}_{4} \mathrm{SiO}_{4}\right)$ are insoluble as stoichiometric compounds, but molar ratios of $\mathrm{SiO}_{2}: \mathrm{Li}_{2} \mathrm{O}$ from about $2: 1$ to about $8: 1$ are avallable. These solutions are mixtures of silicate lons, siliclc acids, and polymeric silica in colloidal suspension.

Samples of Iithium sillcate with $4: 1$ molar ratio of $\mathrm{SiO}_{2}$ : $\mathrm{Li}_{2} \mathrm{O}$ ("Lithsil-4"*) were purchased and analyzed for Impurities that could absorb neutrons or corrode the stainless steelaluminum reactor system. The analyses are shown in Table II.

Table II. Analysis of "Iithsil-4"

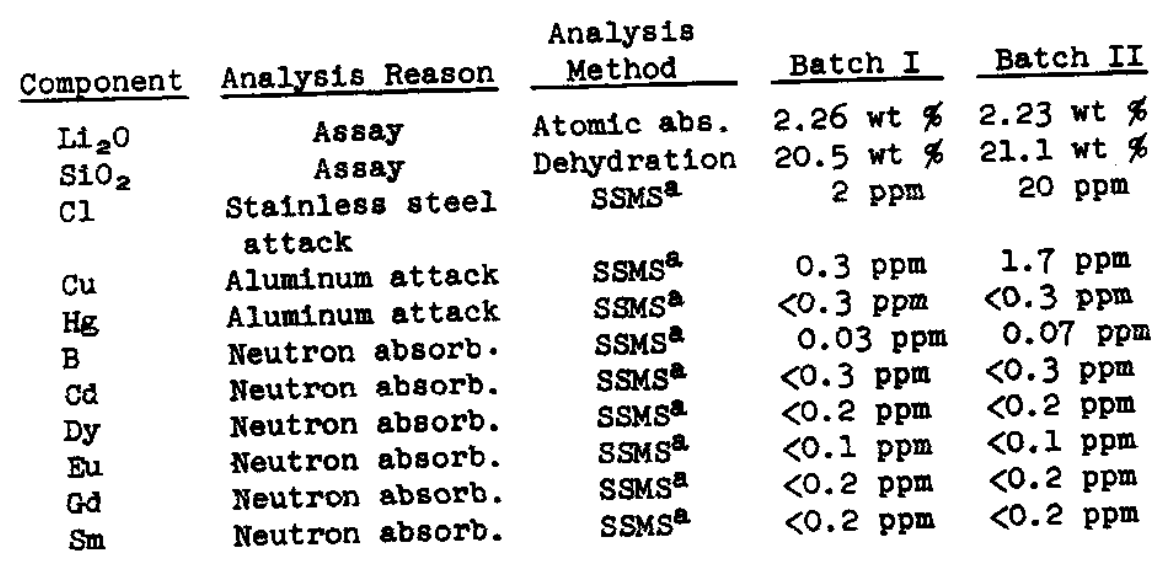

a Spark source mass spectrometer.

The analyses showed that the product was quite pure and satisfactory for addition to the reactor moderator if satisfactory as an inhibitor.

* Trademark of Lithium Corp. of America 


\section{EXPERIMENTAL PROCEDURES}

\section{Filming and Testing Laboratory Specimens}

Two procedures were used to apply a protective lithium aluminosilicate film to aluminum surfaces: 1) Specimens were cleaned in $I M \mathrm{NaOH}$, and rinsed in water; some pieces were also oxidized in steam at $40 \mathrm{psi}$ for $1 \mathrm{hr}$. The specimens were then immersed for 1 hour at $95 \pm 2^{\circ} \mathrm{C}$ in "Lithsil-4" solution containing 500 to $2000 \mathrm{ppm}$ of $\mathrm{SiO}_{2}$. 2) Specimens were cleaned, rinsed, and dipped in a $2 \%$ colloidal suspension of ammonia-stabilized sillca, "Iudox AS"*, at $25^{\circ} \mathrm{C}$. The silica formed an adherent layer of silica particles about $150 \AA$ in diameter that could not be rinsed off the aluminum with water. The protective film was then formed by immersing the aluminum, coated with colloldal silica, in a 750 ppm $\mathrm{SiO}_{2}$ "Lithsil-4" solution at $95^{\circ} \mathrm{C}$ for one hour.

The relative corrosion resistance of the filmed surface was evaluated by determining the time required to attack the aluminum with $1 \mathrm{~g} \mathrm{HgCl} / \mathrm{H}$ or with $0.1 \mathrm{M} \mathrm{HCl}$. Drops of solution were allowed to fall on the filmed surface and observed at $30 x$. The time to produce the first visible bubble was taken as the time to penetrate the protective film. Blanks were mu on freshly cleaned aluminum surfaces.

\section{Filming and Testing Reactor Components}

Reactor components were cleaned by dipping in $0.6 \mathrm{M} \mathrm{NaOH}$ at $60-70^{\circ} \mathrm{C}$ and rinsing in cold water. The insolubles adhering to the component surfaces were removed by dipping in $14 \mathrm{M} \mathrm{HNO}_{3}$ at $80-90^{\circ} \mathrm{C}$, then rinsing in hot process water, and air drying.

The filming steps were started within 16 hours of cleaning. The cleaned surfaces were dipped in 1-2\% "Ludox AS" for 5 minutes and rinsed. The components were then dipped in a flowing delonized-water solution of "Lithsil-4" containing 500-1000 ppm of sillca at $90-95^{\circ} \mathrm{C}$ for 1 hour.

The thickness of the corrosion product f1lm was measured with a "Dermitron"** eddy current tester after six months exposure of the aluminum cladding in the reactor.

\section{Analyses of Silicates}

The silica in "Lithsils" cannot be all soluble ionic species because the solutions are I1thium-deficlent. For example, "IIths11-4" was about 60\% soluble (s111cate, mono and disilicic acids) and 40\% polymeric (trisilicic acid, tetrasillcic, etc.).

* Trademark of E. I. du Pont de Nemours and Co.

* Trademark of Unit Process Assembl1es, Inc., Woods1de, $N . Y$. 
Soluble silicates were determined colorimetrically.3,4

Total silica was normally determined by atomic absorption spectroscopy at $\sim 1 \mathrm{mg} / \mathrm{ml}$. Standards were prepared by dilution of a $20 \% \mathrm{SiO}_{2}$ solution (accurately known from determination by acid-dehydration and volatilization with HF). Total silica in dilute $\left(0.1 \mu g \mathrm{SiO}_{2} / \mathrm{ml}\right)$ and radioactive solutions was determined colorimetrically after a carbonate fusion.

\section{RESULTS}

\section{Laboratory Evaluation of Silicate Inhibitor}

The concentration of inhibitor in the moderator should be minimized to avold overloading the ion exchange resin used for purification. Therefore, a process was devised in which the fuel cladding was coated with silica prior to charging in the reactor, and the coating was maintained by later additions of silicate to the moderator. Silicates lend themselves to this type of application. 5 An aluminum surface treated with lithium silicate will grow a lithium aluminosilicate film. This film will be wetted with water. Traces of grease, o1l, or fatty acids on the aluminum will prevent complete coverage (Figure 2 ).

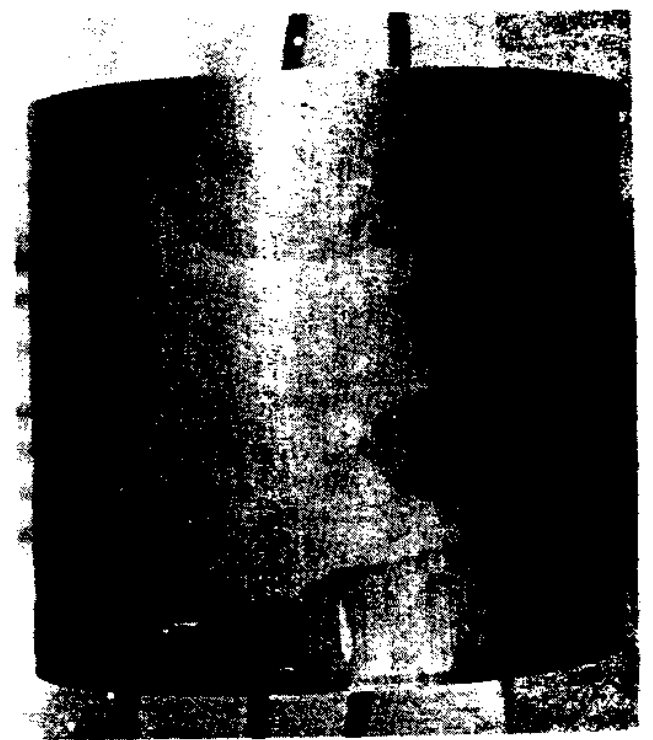

a. Surface free of oils and fats prior to filming. Lightcolored water stain shows uniform wetting.

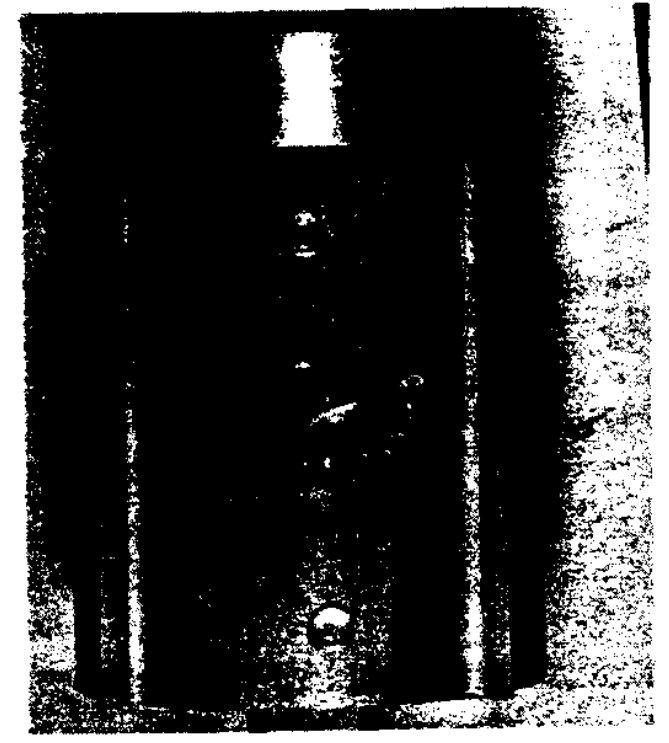

b. Surface improperly cleaned prior to filming. Water forms beads because the aluminosilicate film did not form over oily surface:

FIG. 2 ALUMINUM COMPONENTS FILMED WITH LITHIUM ALUMINOSILICATE 
Autoclaved and unautoclaved 1100 aluminum specimens were corrosion tested in the treated and untreated conditions. Treated specimens were immersed in $500 \mathrm{ppm} \mathrm{SiO}_{2}$ (as "Iithsil-4") for 1 hour at $95^{\circ} \mathrm{C}$. Corrosion resistance was measured in a static heavy water system at $100^{\circ} \mathrm{C}$ and controlled to a deuterium ion concentration of $10^{-5} \mathrm{M}(\mathrm{pD}: 5.1 \pm 0.2)$. Welght gain was used as a measure of corrosion rate. The results are given in Figure 3 . After 10 days, the filming treatment had reduced corrosion $36 \%$ for unautoclaved aluminum and $59 \%$ for autoclaved aluminum.

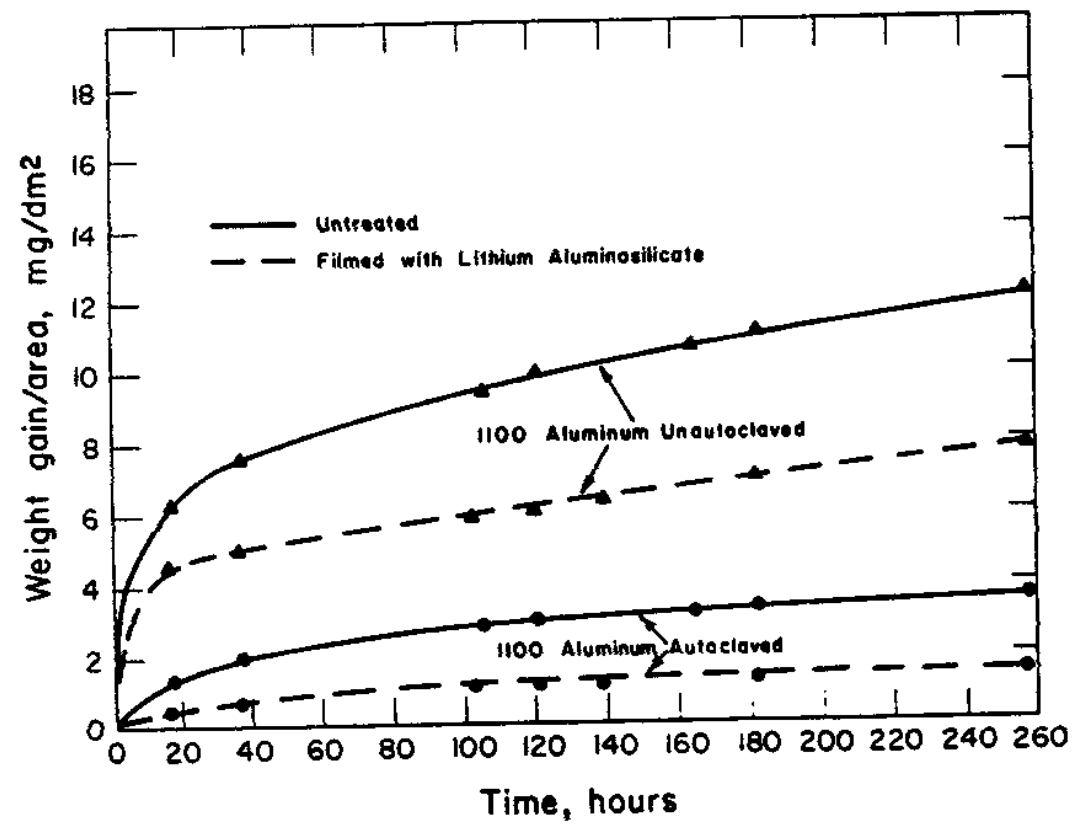

FIG. 3 LABORATORY CORROSION TESTS OF ALUMMUM

To determine optimum f1ming cond1tions, several combinations of I1thium silicate and colloldal silica were tested. Both $1 \mathrm{~g} \mathrm{HgCl} / 2 / l$ and $0.1 \mathrm{M} \mathrm{HCl}$ were used in accelerated corrosion tests. Two treatments are compared in Table III.

Table III. Corrosion Resistance of il:h1um

Aluminosilicate Filmed Aidninum

Treatment

None (blank)

"L1ths11-4" (750 ppm $\mathrm{S1O}_{2}$ )

I-2\% "Ludox", "IIths11-4"

(750 ppm $\mathrm{S1O}_{2}$ )

Average Time to In1t1ate Attack, sec $1 \mathrm{~g} \mathrm{HgCl}_{2} / 2$ :ter $0.2 \times \mathrm{BCl}$

5

40

70

20

140

240 
An improperly cleaned specimen, simulated by dipping the specimen in potassium oleate after cleaning gave erratic results. The majority of erratic results were much shorter than 40 (with I $\mathrm{g} \mathrm{HgCl}_{2} / \ell$ ) or 140 (with $0.1 \mathrm{M} \mathrm{HCl}$ ) seconds. The results in Table III show the advantage of pretreatment of the cleaned aluminum with colloidal silica ("Iudox").

Specimens of 1100 aluminum treated with colloidal slilcalithium silicate were purposely damaged by scratching or drilling to destroy a small portion of the protective film. This damaged area would be anodic to the rest of the specimen. Aqueous corrosion tests of several specimens with defective films did not show any unusual effects, such as accelerated corrosion, after 250 hours.

\section{Reactor Tests - Addition of Silicates to Moderator}

In reactor tests, aluminum corrosion was reduced by forming a thin film of lithium aluminosilicate on fuel cladding, and attempting to maintain the film by addition of small amounts of lithium silicate to the moderator.

\section{Untreated Cladding}

The initial reactor test evaluated the addition of a 0.05 wt $\%$ $\mathrm{SiO}_{2}$ solution of "Lithsil-4" to the moderator to obtain a maximum concentration of $0.2 \mathrm{ppm}$ soluble silica. The soluble silica in the moderator was kept below 0.2 ppm to prevent rapid depletion of the ion exchange resin. The reactor fuel cladding was autoclaved, but was not filmed with lithlum s1l1cate. The addition of lithium silicate to the moderator for 30 days:

did not change the heat transfer coeficlents of the heat exchangers

did not give evidence of major deposition of silica or silicates in the reactor system

did not adversely affect moderator radoectivity, turbidity, $\mathrm{pD}$, or aluminum corrosion.

The concentration of soluble silica (silicates, mono- and disiliclc acids) averaged $0.07 \mathrm{ppm} \mathrm{S1O}_{2}$, and was efficiently removed by the delonizers. The polymeric silica disappeared rapidiy, either by deposition on fuel tubes or by coagulation with alumina and removal in the ion exchange resin beds or in the distillation system. About $300 \mathrm{~g}$ of insoluble silica added to the moderator system were unaccounted for at the completion of the test. 
${ }^{95} \mathrm{Zr}-{ }^{95} \mathrm{Mb}$ and ${ }^{103} \mathrm{Ru}$ fission product concentrations decreased and increased when addition stopped during silicate addition and lnereas not observed for ${ }^{140} \mathrm{Ba}-140 \mathrm{La}$. (Figure 4). A similar decrease was of the ${ }^{10{ }^{2}} \mathrm{Ru}$ are normally The ${ }^{95} \mathrm{Zr}-{ }^{95} \mathrm{Nb}$ and a major portuct turbidity. The ${ }^{140} \mathrm{Ba}-{ }^{140} \mathrm{La}$ associated with corrosion product a mortion of the ${ }^{10{ }^{3} \mathrm{Ru}}$ are normally soluble lons.

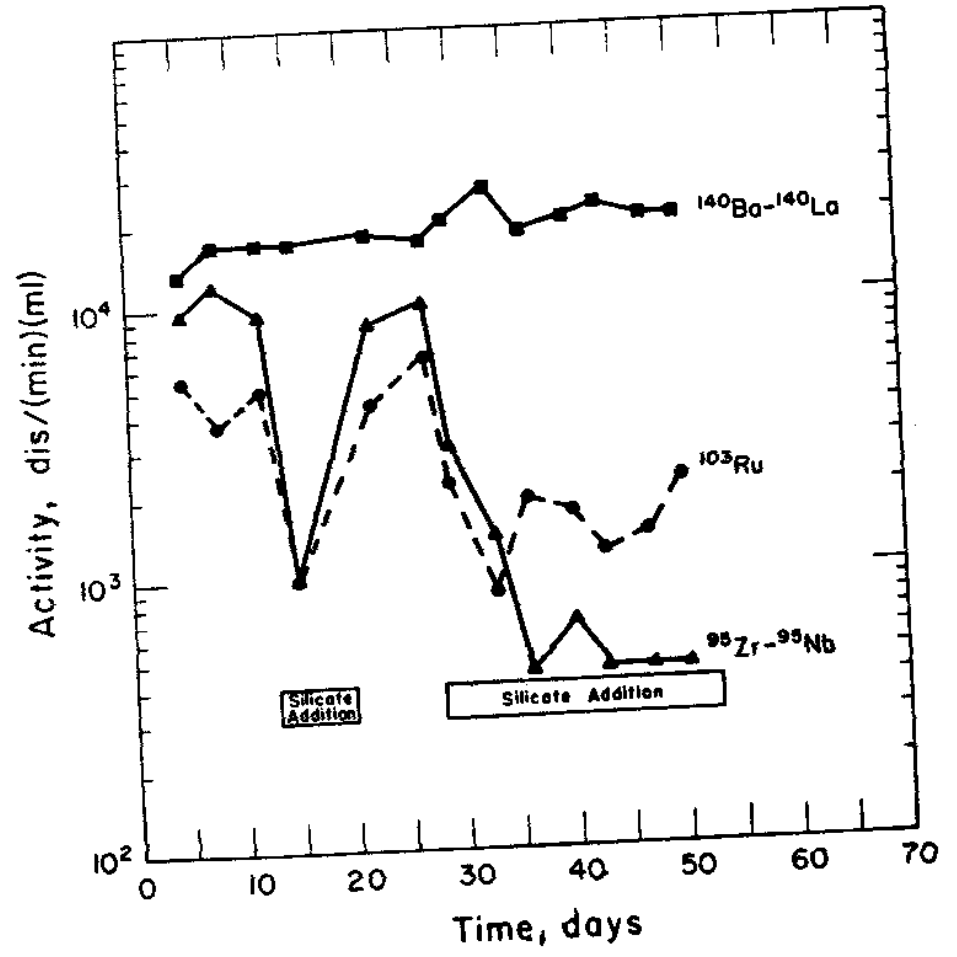

FIG. 4 EFFECT OF SILICATE ADDITION ON MODERATOR ACTIVITIES

Another test was run to determine whether the reduction in to product activity was due to a decrease in fisthil-4" solution was added to turbld moderator reactor operation. The results are shown in Table IV.

Table IV. Effect of Silicate on Mean Turbidity and Activity Levels

\begin{tabular}{|c|c|c|c|}
\hline & $\begin{array}{c}\text { Turbidity, } \\
\mathrm{ppm}\end{array}$ & $\begin{array}{c}\text { Gross } \alpha, \\
\mathrm{d} s /(\min )(\mathrm{ml})\end{array}$ & $\begin{array}{l}\text { Gross } \beta \gamma,,^{2} \\
c /(\min )(m l)\end{array}$ \\
\hline efore $a$ & 10.0 & $20 \times 10^{2}$ & $4.5 \times 10^{5}$ \\
\hline on & $<0.5$ & $3.5 \times 10^{2}$ & $2.7 \times 10^{8}$ \\
\hline additio & 5.0 & $15 \times 10^{2}$ & $6.8 \times 10^{5}$ \\
\hline
\end{tabular}

After 2-hour decay 
The data in Table IV clearly show that the silica lowered the turbidity and the $\alpha$ and $\beta-\gamma$ activity associated with it.

In other tests, turbidity dropped from $9.0 \mathrm{ppm}$ to $1.5 \mathrm{ppm}$ after 8 hours and then to $<0.5 \mathrm{ppm}$ after 16 hours of sillca addition. Total silica was controlled by maintaining soluble silica at $0.1 \mathrm{ppm}$ (but turbidity removal is largely due to polymeric silica ${ }^{8}$ ). Calculations of the highest possible removal rate by the purification system showed that $\angle 50 \%$ of the turbidity should have disappeared. Apparently, the sllica had coagulated the turbldity, and the product was deposited either on the fuel tubes, on the reactor plping, or in the ion exchange beds. No unusual releases of any fission products have been observed during cooling of the spent fuel tubes in water storage basins nor has radioactivity increased around reactor piping. The ion exchange beds were not monitored for activity because the increase would be too small to detect.

The rapid reduction in turbidity was due to the reaction between the positively charged alumina sol and polysilicate. ${ }^{\circ}$ Sillcates are known coagulants. At equal $\mathrm{SiO}_{2}$ concentrations, orthosilicic acid is a much less effective coagulant for the alumina sol than is a solution of polysilicates. This was illustrated by the addition of "IIthsil-2" $\left(\mathrm{SiO}_{2} / \mathrm{LI}_{2} \mathrm{O}=2,<5 \%\right.$ polysilicates) to the reactor moderator. No effect was observed on turbidity or the activity associated with 1 . The large effect of "Lithsil-4" ( $\mathrm{SIO}_{2} / \mathrm{LI}_{2} \mathrm{O}=4$, $40 \%$ polysilicates) on turbidity and activity when added at the same concentration as "Iithsil-2" was described in Table IV.

If a future program is undertaken to determine the most effective $\mathrm{SiO}_{2}$ concentration for turbldity removal, lithium sillcate should be added to the moderator to reach a concentration of $20.05 \mathrm{ppm}$ and the concentration then gradualiy increased. The positively charged alumina sol w1ll be destabilized as the $\mathrm{SiO}_{2}$ concentration is increased. Later, she sol will again become stabllized as a negatively charged s:i:ca specles. The $\mathrm{StO}_{2}$ concentration range between that prodic:r.g the negatively and positively charged sols is optimum ard is a function of the surface area of the original alimina sol turbidity.

The most effective coagulat:cr. : : he alumina sol at the lowest possible silica concentra:1in. w111 be produced by a $\mathrm{S}_{10} \mathrm{O}_{2} / \mathrm{LI}_{2} \mathrm{O}$ ratio of 7 or $8 .^{\circ}$ 


\section{Treated cladding}

In the first test of treated fuel elements, $10 \%$ of the fuel clading surfaces of a reactor charge was treated to form a protective film as described in the experimental section. Sections of treated components are comnared to untreated specimens in Figure 5, which shows that the film was 0.7-0.8 $\mu \mathrm{m}$ thick. Oblique lighting was used in the picture of the cladding surfaces to show the difference in light reflectance on the treated and untreated specimens.

The filmed fuel cladding operated in moderator that contained an average concentration of $0.07 \mathrm{ppm}$ soluble silica. The polysilicates reduced ${ }^{85} \mathrm{Zr-}{ }^{95} \mathrm{Nb}$ fission products by a factor of 10 to $20 ;{ }^{103} \mathrm{Ru}$ was lowered, but ${ }^{24} \mathrm{O} \mathrm{Ba}-24{ }^{\circ} \mathrm{La}$ was not affected, as observed in the reactor test without filmed components.

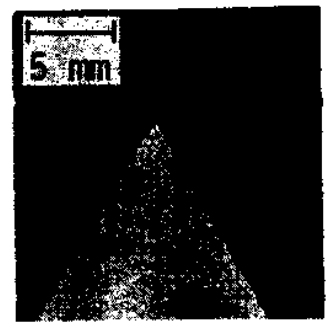

Unfilmed

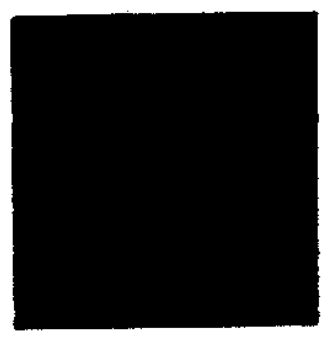

Filmed

SURFACES OF FUEL TUBE SECTIONS

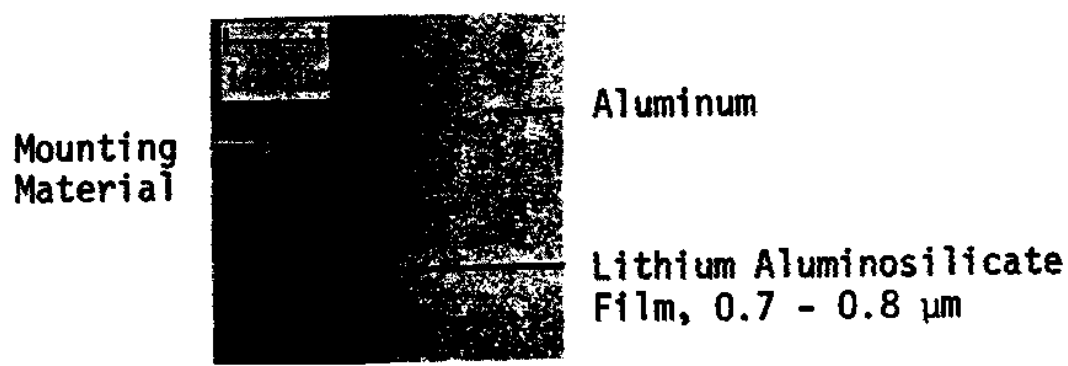

CROSS SECTION OF FILMED SPECIMEN

FIG. 5 SPECIMENS FOR REACTOR TEST 
After six months of operation, the corrosion product thickness on two fuel tubes that had been filmed was compared to the corrosion product thickness on untreated tubes with equivalent neutron exposures (Figure 6). The overall corrosion product thickness on the treated and untreated fuel cladding was equal, but was only about $2 / 3$ of the amount expected for silicate-free operation. The
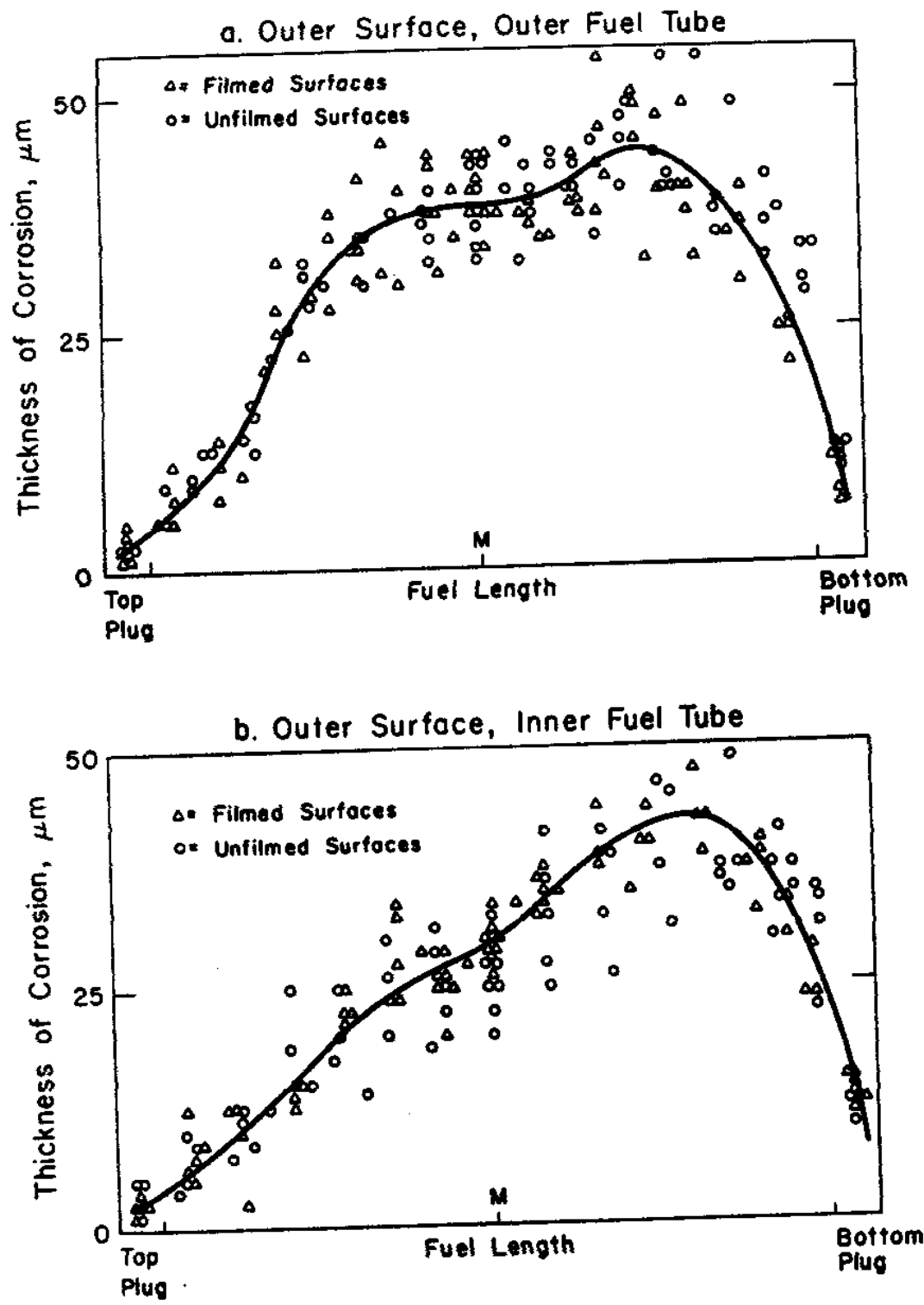

FIG. 6 PROFILE OF CORROSION PRODUCT ON FUEL CLADDING AFTER SIX MONTHS EXPOSURE 
lithium aluminosilicate film produced before reactor loading apparently did not affect the long-term corrosion of the aluminum; therefore, the data from the treated and untreated fuel tubes were plotted together as a single line in Figure 6 . However, the calculated amount of long-term corrosion was reduced somewhat, based on an equivalent charge that had not been exposed to silicate treatment, as shown in Figure 7. The corrosion reduction is probably due to reaction of silicate ions with aluminum. The corrosion thickness was calculated to account for the hydrogen (deuterium) evolution observed in both charges from corrosion of aluminum according to the reaction $2 \mathrm{AI}+4 \mathrm{D}_{2} \mathrm{O} \rightarrow \mathrm{Al}_{2} \mathrm{O}_{3} \cdot \mathrm{D}_{2} \mathrm{O}+3 \mathrm{D}_{2}$. The results implied that the addition of traces of silicate had reduced long-term corrosion about 30\%.

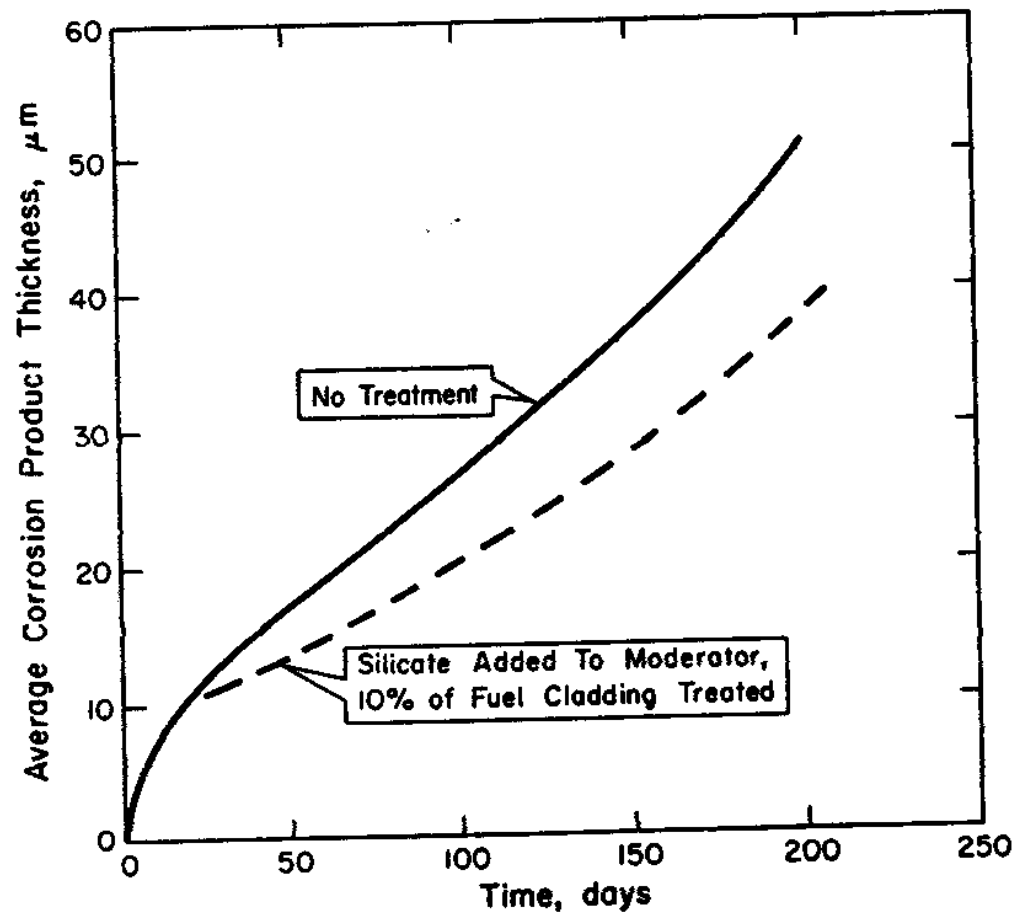

FIG. 7 CALCULATED LONG-TERM CORROSION 
In another reaction test, $90 \%$ of the fuel cladding was treated. The corrosion rate was again calculated on the basis of hydrogen evolution, and is compared for the $10 \%$ treated load and an untreated load (Figure 8). At the end of four days the difference between the treated loads was a maximum; the load that was $90 \%$ filmed showed only half the average corrosion product thickness of the load with $10 \%$ of the clading treated. After four days, the dif ference in the average corrosion product thickness began to decrease; after 60 days, the calculated thickness was the same for both loads. The short-term reduction in the average corrosion flim thickness was

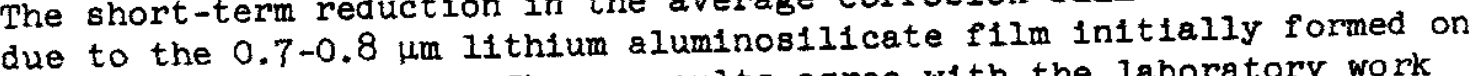
the cladilng surfaces. These results agree with the laboratory work on unautoclaved surfaces that showed a $36 \%$ reduction after 10 days.

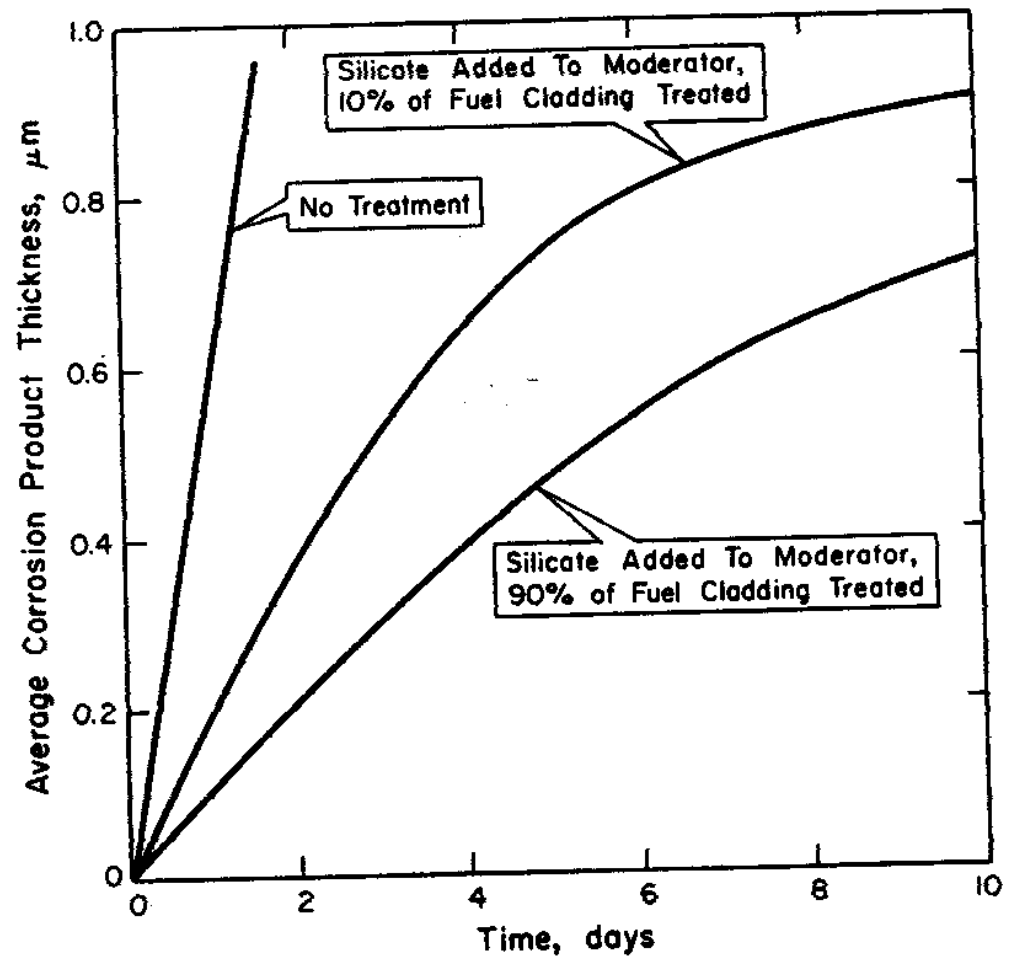

FIG. 8 CALCULATED SHORT-TERM CORROSION 
The long-term reduction in corrosion is believed to be due to. addition of soluble silicates to the moderator, rather than the pretreatment of the cladding, and the effect was equivalent to the previous reactor test.

The ineffectiveness of the $0.7-0.8 \mu \mathrm{m}$ ilthium aluminosilicate film after 60 days was not surprising, because only $\sim 1 / 20$ of the silica normally used to inhibit corrosion was added to the moderator to maintain the film. The film was apparently disrupted by the growth of aluminum oxide at the cladding surface as oxygen diffused through the film. After 60 days the aluminum oxide coating was $20-25 \mu \mathrm{m}$ thick.

\section{ACKNOWLEDGMENTS}

The author thanks W. R. Jacobsen who supplied most of the reactor data in this report, W. $R$. Kritz for. the oxide film thickness measurements, and F. B. Longtin for technical discussions.

\section{REFERENCES}

1. G. N. Flannagan and R. F. Anderson. "Quality Control of Moderator in Savannah River Plant Reactors." 147 th Meeting of the American Chemical Society, Philadelphia, April 6-10, 1964.

2. I. L. Shreir. Corrosion. p. 18, 37, John Wiley, New York (1963).

3. R. J. VoIk and R. L. Weintraub. "Microdetermination of Silicon in Plants." Anal. Chem. 30, 1011 (1958).

4. G. Charlot. Colorimetric Determination of the Elements. p. 372, Elsevier Publishing Co., New York (1964).

5. N. D. Tomashov. Theory of Corrosion and Protection of Metals. p. 303, The Macmilian Co. New York (1966).

6. W. Stumm, H. Huper, and R. L. Champlin. "Formation of Polysilicates as Determined by Coagulation Effects." Environ. Sci. Tech. 1, 221 (1967). 